\title{
Contribution to the systematics and zoogeography of the East-African Acomys spinosissimus Peters 1852 species complex and the description of two new species (Rodentia: Muridae)
}

\author{
WALTER VERHEYEN ${ }^{1,6}$, JAN HULSELMANS ${ }^{1}$, WIM WENDELEN ${ }^{2}$, HERWIG LEIRS ${ }^{1}$, MARCO CORTI ${ }^{3,6}$ \\ THIERRY BACKELJAU ${ }^{1,4}$ \& ERIK VERHEYEN ${ }^{1,4,5}$ \\ ${ }^{1}$ University of Antwerp, Biology Department, Groenenborgerlaan 171, B-2020 Antwerp, Belgium. \\ E-mail: jan.hulselmans@ua.ac.be; herwig.leirs@ua.ac.be, thierry.backeljau@ua.ac.be \\ ${ }^{2}$ Royal Museum for Central Africa, Department African Zoology, Vertebrate section, Leuvense steenweg 13, B-3030 Tervuren, Bel- \\ gium.E-mail: wim.wendelen@africamuseum.be \\ ${ }^{3}$ Universita di Roma “La Sapienza, Dipartimento di Biologia Animale e dell'Uomo, Via Borelli 50, 00161, Roma, Italy \\ ${ }^{4}$ Royal Belgian Institute of Natural Sciences, Vertebrate Department, Vautierstraat 29, 1000 Brussels, Belgium. \\ E-mail: thierry.backeljau@naturalsciences.be; erik.verheyen@naturalsciences.be \\ ${ }^{5}$ Corresponding author. E-mail: erik.verheyen@naturalsciences.be \\ ${ }^{6}$ This paper is dedicated to Walter Verheyen and Marco Corti, both passed away before this study was completed
}

\begin{abstract}
We revised the taxonomic status of the putative Acomys spinosissimus complex based on the comparative study of specimen collections from Tanzania, Zambia, Zimbabwe, Mozambique, DR Congo and South Africa, by means of analysis of external morphology, craniometry, enzymes, mitochondrial DNA sequences and karyology. Our results confirm that $A$. spinosissimus represents a complex of species with seemingly non-overlapping distribution ranges. The distribution range of A. spinosissimus appears to be restricted between the Zambesi and Limpopo Rivers, while the reinstated A. selousi (that includes A. transvaalensis) occurs further to the South (i.e. northern limit seemingly just north of the Limpopo River). The investigated populations north of the Zambezi River are morphologically and genetically distinct from A. spinosissimus and A. selousi. Based on this evidence, we described Acomys muzei sp. nov. and Acomys ngurui sp. nov., each one occurring separately along one side of the Eastern Arc Mountains. Finally, we lacked sufficient information to describe a third new species from the area north of the Zambesi River.
\end{abstract}

Key words: Acomys spinosissimus, taxonomy, cytochrome $b$, craniometry, morphology, enzymes

\section{Introduction}

Acomys or spiny mice are widespread throughout all of Africa, the near and Middle East, and some Mediterranean islands (Corbet 1978). This genus has been the subject of several molecular and morphological analyses due to their basal phylogenetic position within the Muridae (Sarich 1985; Denys et al. 1992 a, b; Chevret et al. 1993; Chevret \& Hänni 1994; Hänni et al. 1995).

Since 1939, when G. M. Allen listed the recorded African species of Acomys in his "Checklist of African Mammals" (Allen 1939), African members of the genus have been the subject of a series of studies that resulted in different species lists (e.g. Setzer 1975). The most recent annotated checklist recognizes 19 species, but as for many other African rodent genera, their taxonomy requires further study (Musser \& Carleton 2005).

To date, the information available for documenting species-limits in Acomys includes chromosomal studies and reviews (Matthey 1954, 1956, 1963, 1965a,b, 1968; Volobouev et al.1991; Sokolov et al. 1992, 1993; Denys et al. 1994; Volobouev et al. 2007); studies of cranial characters and morphology of molars (Petter 1983; Denys et al. 1994), morphology of spermatozoa (Baskevich \& Lavrenchenko 1995) and allozyme and mtDNA studies of species-assemblages (Janecek et al. 1991; Barome et al. 1998, 2000, 2001). The significant contribution by Dippenaar 